\title{
Teorijsko-metodološki aspekti pristupa životne povijesti u sociologiji*
}

DOI: $10.5613 /$ rzs.49.3.3

UDK: $316: 303.442$

303.442

Pregledni rad

Primljeno: 30. 4. 2019.

\author{
Marija LONČAR \\ Filozofski fakultet Sveučilišta u Splitu, Hrvatska \\ marija.loncar@ffst.hr \\ Zorana ŠULJUG VUČICA \\ Filozofski fakultet Sveučilišta u Splitu, Hrvatska \\ zorana@ffst.hr

\section{Tea BUBIĆ} \\ DOMINE - organizacija za promicanje ženskih prava, Hrvatska \\ bubic.tea@gmail.com
}

\section{SAŽETAK}

lako su tendencije brojnih istraživača dugi niz godina bile usmjerene prema kvantitativnim metodama i statističkim procedurama te pojedinim kvalitativnim metodama i izvorima podataka, posljednjih godina brojni autori govore o uočenom povećanju interesa prema pristupu životne povijesti. Svoje značajne začetke životna povijest bilježi upravo u sociologiji. Unatoč tomu, područje sociologije u Hrvatskoj i dalje ne pokazuje znatniji interes za raspravom teorijskih i metodoloških aspekata životne povijesti. Ovisno o interesima istraživača, životna povijest može se promatrati kroz različite perspektive, kao teorijsko-metodološki okvir, ali i kao metoda istraživanja. Ona omogućuje načine dubinskog dokumentiranja individualnih priča unutar društvenog konteksta tijekom određenog vremena te je pogodna za istraživanje širokog spektra fenomena što ističe metodološku snagu ovog pristupa. Unatoč tomu, kao i kod drugih kvalitativnih pristupa, i kod životne povijesti pojavljuju se pitanja vezana uz refleksivna razmatranja istraživačkog dizajna, te ostala specifična metodološka i etička pitanja. S druge strane, njezine metodološke i istraživačke prednosti u istraživanjima brojnih društvenih fenomena upućuju na potrebu razmatranja uloge pristupa životne povijesti u suvremenoj sociološkoj metodologiji.

Ključne riječi: pristup životne povijesti, sociologija, kvalitativna metodologija, istraživački pristupi i metode

Rad je djelomično proizašao iz diplomskoga rada Bubić T (2016): Društvena konstrukcija emotivnih obrazaca ponašanja: primjena life history metode, obranjenog na Filozofskom fakultetu u Splitu. 


\section{UVOD}

Its future cannot be predicted

Razvoj sociologije kao discipline obilježen je teorijskim i metodološkim "trendovima", što se može ilustrirati njezinim odnosom prema kvalitativnim istraživačkim pristupima i metodama. Empirijska sociologija se tijekom duljega vremenskog perioda fokusirala na tzv. "znanstvene metode" i njihove specifičnosti. S druge strane, s konceptom metodološkog pluralizma u prvi plan dolaze značajke drugih pristupa i metoda (Bertaux i Kohli, 1984: 216). Upravo se tendencije istraživača prema kvantitativnim metodama i statističkim procedurama smatraju jednim od razloga odbacivanja životne povijesti (eng. life history) (kao kvalitativnog pristupa) među društvenim znanstvenicima (Goodson, 2001; Miller, 2003). Ipak, posljednjih četrdesetak godina uočava se povećan interes za taj pristup i njegove teorijske, metodološke i istraživačke mogućnosti (Goodson, 2001; Ojermark, 2007; Miller, 2003; Plummer, 1990, 2001; Bertaux i Kohli, 1984, Kouritzin, 2000). Unatoč tomu, među daljnjim razlozima zanemarivanja također se spominju i tendencije sociologa prema korištenju drugih (kvalitativnih) metoda i izvora podataka te naglašavanju situacija i značenja kao kolektivnih/grupnih konstrukcija, umjesto individualnih biografija. Goodson pritom ističe paradoksalne okolnosti u kojima se pod utjecajem novih pravaca ${ }^{1}$ napravio odmak od pozitivističke paradigme, ali se istodobno pristup životne povijesti zanemario (Goodson, 2001, 134-136).

U metodološkoj literaturi, studija Thomasa i Znanieckog - Poljski seljak u Europi i Americi (u originalu, The Polish Peasant in Europe and America) - navodi se kao početak razvijanja životne povijesti (Goodson, 2001; Adriansen, 2012; Abu Bakar i Abdullah, 2008; Miller, 2003). Razdoblje čikaške škole dalje se naglašava kao "zlatno doba" (Kouritzin, 2000) tijekom kojeg se učvrstila pozicija životne povijesti (Goodson, 2001; Abu Bakar i Abdullah, 2008). Stoga se čikaška škola i studija Thomasa i Znanieckog iz dvadesetih godina 20. stoljeća dovode u vezu s početcima sociološkoga biografskog istraživanja i životne povijesti (Plummer, 1990, 2001; Rosenthal, 2004). Autori su suglasni da otad doživljava svoje uspone i padove (Goodson, 2001; Adriansen, 2012; Kouritzin, 2000), kako u sociologiji tako i društvenim znanostima općenito. Ojermark (2007) smatra da iako svoje snažni-

$\mathrm{Na}$ tragu razumijevanja glavnih strujanja u sociologiji, Plummer (1990) polazi od (in)direktnog doprinosa Blumera u razumijevanju životne povijesti i rasprava o kriterijima vrednovanja kvalitativnih pristupa. $S$ druge strane, pitanja valjanosti u interpretativnim pristupima općenito nalaze se u središtu metodoloških rasprava još od sedamdesetih godina 20. stoljeća (Bertaux i Kohli, 1984). 
je začetke ima u sociološkoj disciplini, pristup životne povijesti specifičnim čini i njegova primjena u brojnim drugim disciplinama i područjima što sa sobom nosi određene terminološke poteškoće. Ujedno tako različita shvaćanja životnih povijesti kao "metodološkog stila" (Ojermark, 2007) i /ili "istraživačkog žanra" (Dhunpath, 2000) također podcrtavaju važnost rasprava o kvalitativnim pristupima u suvremenoj sociološkoj metodologiji.

Subjektivnost, kriteriji valjanosti i refleksivna pozicija istraživača neke su od ključnih metodoloških odrednica onih pristupa koji dovode u pitanje uobičajene koncepcije istine, stvarnosti i prikazivanja istih (Lončar, 2010; Goodson, 2001; Dhunpath, 2000; Plummer, 2001). Labaree (2006) u tom pogledu ističe kako kriterij valjanosti i pozicioniranost istraživača unutar teksta pridonose tvrdnjama pouzdanosti (u rezultate) životne povijesti. Naime, taj pristup pruža uvide u živote drugih, pri čemu je ključno shvatiti da je ono što istraživač prikazuje zapravo konstrukcija (nečije) stvarnosti (Merriam prema Labaree, 2006: 134). Na istoj liniji argumentacije, važno je prepoznati kako životna povijest uključuje ko-konstrukciju priče u kojoj sudjeluju istraživač i sudionik (Labaree, 2006: 135). U konačnici nam "otkriva" priče kroz interakciju individualnih iskustava i institucionalnih okvira, odnosno društvenog konteksta (Labaree, 2006; Dhunpath, 2000). Bolje razumijevanje tako proizvedenog teksta, ističe Wengraf (2000), ne zahtijeva samo iscrpno poznavanje konteksta, povijesti i subjektivnosti, nego i znanje o tekstovima. Drugim riječima, adekvatno razumijevanje životnih priča uključuje analizu svih četiriju navedenih komponenti.

Pritom se, dakako, postavlja pitanje kako pojedinačna iskustva i životne priče mogu pridonijeti razumijevanju grupnih i kolektivnih značenja i iskustava. Wengraf poentira da nema prekida u povezanosti pojedinačnih i grupnih slučajeva, jer analiza pojedinačnih slučajeva započinje upravo primjenom općih koncepata kojima se daje smisao pojedinačnim slučajevima (Wengraf, 2000: 148-149). Drugim riječima, neki se individuum i njegova životna priča razmatra s pomoću općih kategorija roda, spola, etničke pripadnosti, mjesta i vremena življenja (kao što su npr. otac, stanovnik, radnik, Hrvat itd.), tj. općih koncepata (kao što su obitelj, kućanstvo, brak, vrsta društva, tip političkog uređenja itd.).

Kao i kod drugih kvalitativnih pristupa, određena problematika vezana uz životnu povijest nije (isključivo) tehničko nego ključno metodološko pitanje (Kouritzin, 2000) koje uključuje refleksivna razmatranja kod izbora istraživačkog dizajna (odabira sudionika, prikupljanja, analiziranja i prikazivanja podataka) (Ojermark, 2007), te brojnih drugih metodoloških pitanja (valjanosti, pouzdanosti, refleksivnosti ...) i etičkih razmatranja (poput pitanja vlasništva, odnosa moći, glasa ...) (Goodson, 2001; Labaree, 2006; Plummer, 2001). Istodobno, u okviru tih uvodnih razmatranja, treba naglasiti kako se pristup životne povijesti može smjestiti 
unutar raspona različitih teorijskih orijentacija (mikro, makro...) koje pokrivaju niz (različitih) pitanja stavljajući fokus(e) na subjektivna stajališta, rekonstrukciju značenja ili prepoznavanje društvenih obrazaca. Unutar tih pitanja i teorijskih okvira istraživači se susreću i s različitim metodološkim odlukama (Bertaux i Kohli, 1984: 218-219). Imajući na umu različite tendencije u suvremenoj sociološkoj metodologiji i njezin razvoj unutar društvenih znanosti u Hrvatskoj, ovaj rad polazi od važnosti rasprava o kvalitativnim pristupima kao što je životna povijest i njezinim doprinosima u sociološkim istraživanjima. Na tragu toga, moguće je uočiti da osim ponekoga istraživačkog rada s manje ili više eksplicitnim ukazivanjem na primjenu pristupa životne povijesti, područje sociologije u Hrvatskoj ne pokriva rasprave o teorijskim i metodološkim apektima spomenutog pristupa.

\section{ISTRAŽIVAČKO PITANJE: "PRISTUP” FENOMENIMA I SUGOVORNICIMA}

Svijet je prepun osobnih dokumenata, kao što su dnevnici, pisma, fotografije, bilješke, auto/biografije, web stranice, memoari, životopisi, videodnevnici, natpisi na nadgrobnim spomenicima, slike itd. Sve te raznolike izraze osobnog života Plummer naziva "dokumentima života" (Plummer, 2001: 17). Životna priča jedan je od najvažnijih primjera prikaza života jedne osobe ispričana njezinim/njegovim vlastitim riječima. Ona omogućuje istraživačima ulazak u njihov subjektivni svijet, pri čemu se razmatraju unutar vlastitih okvira pružajući tako osobne prikaze života. Životne priče dolaze kroz mnoštvo izvora kao što su biografije, autobiografije, pisma, časopisi, intervjui, osmrtnice itd. Može ih napisati osoba kao vlastitu životnu priču (autobiografiju) ili vlastitu fikciju. One mogu biti njihova priča koju je izvukao netko drugi ili njihova "vlastita priča" koju je ispričao netko drugi (kao u biografiji). Također mogu postojati u različitim oblicima, biti duge i kratke, prošle i buduće, specifične i općenite, obične i izvanredne, nejasne i fokusirane, površne i duboke, realistične i romantične, modernističke i postmodernističke. $S$ druge strane, u literaturi su označene različitim pojmovima kao što su životne priče, životne povijesti, životne narative, autobiografije, usmene povijesti, osobni testamenti, životni dokumenti (Plummer, 2001: 18-19). ${ }^{2}$ Kouritzin navodi kako se životna povijest s obzirom na interese istraživača može različito koristiti. Međutim, izdvaja dvije kategorije: životna povijest kao teorijsko-metodološki okvir i kao vrsta intervjua, kako

2 Životna povijest u literaturi se katkad navodi kao jedan od biografskih (Goodson, 2001; Miller, 2003) i narativnih (Goodson, 2001; Dhunpath, 2000) pristupa/istraživanja. S druge strane, neke od ključnih razlika, ali i sličnosti među terminima poput biografskog istraživanja, usmene povijesti, narativnog istraživanja, životne povijesti, životne priče i sl. mogu se naći kod Ojermark (2007). 
bi naglasila ono specifično ${ }^{3}$ u njezinoj primjeni. Kod tih kategorija, Kouritzin ističe bitnu razliku te naglašava kako životna povijest u svojoj razradi uključuje više od životne priče (Kouritzin, 2000: 3-4).

Razlikovanje termina životna povijest i životna priča ističe se važnim zbog njihova nerijetkog korištenja kao istoznačnica, iako oni to nisu (Goodson, 2001; Adriansen, 2012; Kouritzin, 2000; Labaree, 2006; Miller, 2003). Goodson, primjerice, razliku između životne povijesti i životne priče prikazuje kroz različite faze interpretacije. Naime, životnu priču vidi kao početnu točku istraživačkog rada, pri čemu je riječ o pričama udaljenima od "životnog iskustva" (eng. life experience) te interpretiranima u smislu parcijalnih i selektivnih prikaza "proživljenog iskustva" (eng. lived experience). Pomak prema životnoj povijesti uključuje društveni i povijesni kontekst, pri čemu se životne priče promatraju u svjetlu promjenjivih obrazaca i djelovanja kao društvenih konstrukcija (Goodson, 2001: 138-139). Adriansen također ukazuje na ključne dimenzije u razlikovanju termina ${ }^{4}$ te ističe kako je fokus životne priče na razumijevanju osobnih perspektiva i prikaza života (Goodson i Sikes prema Adriansen, 2012: 41). S druge strane, tendencija je životne povijesti razumijevanje povezanosti društvenoga, povijesnog, političkog... konteksta s obrascima različitih životnih priča (Adriansen, 2012: 41). Kao što Wengraf ističe, gotovo je nemoguće potaknuti neki iskaz individualnog života bez uključivanja i primjene općih koncepata, znanja o subjektivnosti, kontekstima i povijesti i bez razmatranja njihove međusobne povezanosti (Wengraf, 2000: 156).

Plummer ističe kako je nužno razmotriti životnu povijest i kao resurs i kao temu. Produkcija bilo kojeg iskaza života, pa tako i životne povijesti, je zapravo tema koju treba istražiti ili objekt interesa. Stoga su bitne informacije o tome kako je došlo do pričanja priče, kako se ona oblikovala, koje je posljedice imala na život onoga koji ju priča, kako je postala tekst, koja je uloga toga teksta i samoga istraživača te koji su njegovi potencijalni čitatelji. Time je životna povijest konstrukcija koja nastaje kroz interakciju i ne možemo je shvatiti samo kao naraciju koju Plummer smatra reprezentacijom života ili "zamrznutom slikom". Životna priča podrazumijeva značenja koja oni koji pričaju daju svom životu, motive koji su skriveni iza njihovih djelovanja, njihove prošlosti i budućnosti. Drugim riječima, pojedinci kroz životne priče neprestano rekonstruiraju sebe i time im se uvijek treba pristupiti kao društvenim objektima i objektima istraživačkog interesa, a ne samo kao resursima (Plummer, 1990: 132-133).

3 Time zapravo ukazuje na različiti odnos prema životnoj povijesti, odnosno njezinom korištenju kao dopune drugim pristupima/metodama ili kao svrhe istraživanja same po sebi. Abu Bakar i Abdullah (2008), primjerice, smatraju kako životna povijest može biti korištena na oba načina, dok se Kouritzin (2000) ipak fokusira na ovaj drugi način.

4 Treba također napomenuti kako navedene razlike ne impliciraju isključivo metodološka, nego i etička pitanja (Goodson, 2001; Adriansen, 2012). 
Pristup životne povijesti omogućuje načine dubinskog dokumentiranja individualnih priča tijekom određenog vremena (Labaree, 2006: 123). Neke od ključnih karakteristika životne povijesti - razumijevanje kompleksnih društvenih interakcija, davanje "glasa" proživljenom te uključivanje čitatelja u interpretativni proces kroz priče pojedinaca ispričane njihovim vlastitim riječima (Cole i Knowles prema Labaree, 2006: 122-123), podcrtavaju tvrdnje spomenutih autora, ali i metodološku snagu životne povijesti. Taj pristup, dakle, pruža uvid u proživljenu stvarnost, otvara prostor marginaliziranim glasovima s ciljem istraživanja subjektivnih iskustava i značenja koja se pridaju pojedinačnim ili međusobno povezanim životima te analiziranja specifičnih načina života (Abu Bakar i Abdullah, 2008: 4).

Pogodan je za istraživanje širokog spektra fenomena, pri čemu se čitateljima omogućuje identificiranje s istraživačkim pitanjima, odnosno "subjektima" istraživanja i time postiže bolje razumijevanje devijantnosti, marginaliziranosti, nasilja u obitelji, nejednakosti... (Gmelch prema Kouritzin, 2000: 17). Čitanje životnih priča daje tim problemima ljudsko lice, što dovodi do poštovanja i razumijevanja problema drugih kroz percipiranje vlastitog živote iz tuđe perspektive (Kouritzin, 2000: 17). Osoba se smješta unutar klase, roda, generacijske grupe, odnosno unutar marginalizirane grupe. Njihove priče, ističe Plummer, nadilaze tradicionalnoga izoliranog pojedinca iz klasičnih autobiografija i idu prema kolektivnoj svijest drugih. Osobna je priča sada priča o skupini ljudi, pri čemu njihov problem iznesen kroz glas pojedinca postaje javni problem. Stoga je nužno usmjeriti se na trenutke pojavljivanja različitih priča o odbačenima i utišanima ${ }^{5}$ te njihovu snalaženju u širem društvu. To su priče siromašnih, priče delinkvenata, ženske autobiografije, narativi ropstva, priče ljudi koji su preživjeli holokaust, gay priče, priče različitih generacija, priče o zdravlju, narativi o AIDS-u itd. (Plummer, 2001: 90-91). Od kraja 20. stoljeća sve se više različitosti u ljudskim životima pojavljuje u obliku životne priče. Vidljiv je značajan "pomak od dominantne priče, dominantnih žanrova, dominantnih sjećanja prema jeziku otpora, alternative i različitosti” (Plummer, 2001: 95-96).

Životna povijest je holistički, dinamički proces koji uključuje retrospektivno životno iskustvo sudionika i istraživačevu interpretaciju. Sukladno tomu, sugovornici istraživačima predstavljaju kolaborativne partnere uključene u istraživanje, otkrivanje i razumijevanje. Sudionici aktivno pamte i rekonstruiraju svoje živote pričajući vlastitu priču. Istraživač vodi sugovornika kroz njegovu/njezinu životnu povijest, potičući sjećanja i ispitanikove refleksije, interpretacije i shvaćanja. Taj pristup pru-

5 Brojni su autori u svojim radovima prepoznali kako je upravo zbog svojih metodoloških posebnosti pristup životne povijesti adekvatan $u$ istraživanjima ranjivih grupa i utišanih glasova (Ojermark, 2007; Abu Bakar i Abdullah, 2008), onih koji su na marginaliziranim pozicijama s obzirom na odnose moći u društvu (Goodson, 2001), etnicitet, rod i/ili zdravstveno stanje (Sosulski i dr., 2010), ili u razumijevanju "Drugih" (Tierney, 1998, 2013). 
ža podatke koji pomažu istraživaču dobiti uvid u to kako su prošli događaji i odnosi utjecali na trenutačni fenomen i kako se shvaćaju vlastiti životi (Haglund, 2004: 1). Točnije, započinje nečijom životnom pričom koja se tijekom iznošenja nadograđuje dodatnim informacijama, tj. društvenim kontekstom (Abu Bakar i Abdullah, 2008: 4). Životna povijest tako nudi mogućnost pristupa društvenom svijetu koji okružuje sugovornika kroz detaljne opise djelovanja, događaja, odnosa i životnih uvjeta, jer životna priča ne može biti ispričana bez konstantnog referiranja na povijesne promjene. Drugim riječima, ona omogućuje razumijevanje društvenih promjena kroz interpretaciju života u prošlosti i sadašnjosti kao i kroz predviđanja nekih budućih promjena (Abu Bakar i Abdullah, 2008: 6).

Pristup životne povijesti pruža obuhvatniju perspektivu od one proizišle iz promatranja ili korištenjem drugih metoda, poput ankete. Stoga se primjenjuje u različitim disciplinama i mnoga istraživanja koriste njegove prednosti fokusirajući se na raznolike teme kao što su spol/rod i feministička pitanja (Sosulski, Buchanan i Donnell, 2010), žene i rad (Abu Bakar i Abdullah, 2008), samoubojstva među muškarcima (River i Fisher, 2015), migracije i siromaštvo, socijalni kapital u obrazovnim institucijama (Tierney, 2013), kultura i povijest nekog mjesta (Adriansen, 2012), istraživanje adolescentske problematike (Haglund 2004), istraživanje obrazovanja (Kouritzin, 2000) itd. Pritom navodimo i neka od istraživanja u Hrvatskoj s pristupom životne povijesti pitanjima kao što su ekonomski aspekti fenomena ovisnosti o drogama (Lalić, 1995) te profesionalna socijalizacija mladih znanstvenica u visokoobrazovnom i znanstvenom sustavu (Brajdić Vuković, 2017; Brajdić Vuković i Vignjević, 2017).

Međutim, kako bismo razumjeli ljudske živote, potrebno je dubinsko razumijevanje konteksta u kojem je smješten nečiji život. Bez kontekstualnih informacija, životne priče ostaju izolirane od uvjeta unutar kojih se konstruiraju (Goodson, 2001: 139). Kontekst je sveprisutna pozadina koja utječe na način života i interpretaciju istoga, koji su događaji, misli, iskustva i odnosi filtrirani i čemu su pridana značenja. Kontekst nije jedinica analize u istraživanju životne povijesti, ali je značajan pri razumijevanju života, događaja u životu i određenog iskustva. Podatke prikupljene pristupom životne povijesti karakterizira bogatstvo i kompleksnost kontekstualnih informacija (Haglund, 2004: 1-2).

Odabir sugovornika ključan je za uspjeh svakog projekta. Caughey (2006) ističe da u svakom projektu životne povijesti postoje dva sudionika, jedan je istraživač/intervjuer, a drugoga je nužno pronaći. Taj drugi trebala bi biti osoba koja istraživaču, s obzirom na sličnosti i različitosti od njega samoga, omogućuje bolje sagledavanje i uočavanje kulturne dimenzije obaju života, i vlastitoga (istraživačevog) i sudionikovog. S obzirom na to da su životno-povijesni intervjui osobni susreti koji dubinski istražuju misli, osjećaje i ponašanja pojedinaca, ponekad je teško uspostaviti od- 
nos iz kojeg proizlazi opsežna životna priča. Savjetuje se izrada liste potencijalnih sudionika istraživanja temeljena na tome kako bi bilo raditi s njima, zašto su nam zanimljivi, jesu li slobodni i kada, kao i neke karakteristike poput refleksivnog osvrta, pričanjem priče te interes i entuzijazam za projekt (Caughey, 2006: 24-26). Drugim riječima, životne povijesti rijetko se oslanjaju na slučajan odabir sudionika. Labaree se slaže da načini provedbe i odabira sugovornika koje predlaže Patton mogu ići u smjeru: intenzivnog uzorkovanja slučaja u kojem su podatci namijenjeni pojašnjavanju relevantnih faktora za istraživanje; raznolikog uzorkovanja u kojima se dokumentiraju sličnosti među heterogenim grupama s ciljem otkrivanja jedinstvenih slučajeva ili zajedničkih obrazaca grupe; uzorkovanja kritičnih slučajeva radi prikupljanja dubinskih informacija; namjernog uzorkovanja sudionika u svrhu dubljeg razumijevanja određenog problema ili fenomena (Patton prema Labaree, 2006: 125). Odabir sudionika uključivat će i aspekte dostupnosti, prigodnosti i sl. (Goodson i Sikes prema Labaree, 2006: 125).

Prikupljanje i analiziranje životnih priča započinje prije svega odgovarajućim istraživačkim pitanjima i razmatranjem problema s kojima se istraživači mogu susresti. Tako Plummer sugerira pitanja koja si istraživači mogu postaviti u bilo kojoj fazi svoga rada. Najprije se postavljaju sadržajna pitanja koja se bave konkretnim, empirijskim područjem koje se želi istražiti. Što istraživač doista želi doznati? Zatim slijede pitanja društvenih znanosti koja se bave vrstom znanja koje se želi proizvesti. Je li istraživač u potrazi za "stvarnim životom" ili za interpretativnim razumijevanjem? Pritom je najčešće riječ o istraživačkim opravdanjima za prikupljanje baš određenih podataka. Zašto baš oni? Nakon toga dolaze tehnička pitanja koja se odnose na odabir sudionika, obavljanje intervjua na najbolji mogući način, analizu. Ta se pitanja bave "kako?" aspektima. Zatim se uključuju etička i politička pitanja s obzirom na politička opravdanja za određenu studiju i etičke implikacije koje su u nju uključene. Istraživanje se vidi kao društvena aktivnost. Iskorištava li to istraživanje nekoga? Donosi li neke korisne pozitivne aspekte marginaliziranoj skupini? Konačno se postavljaju i osobna pitanja koja podrazumijevaju dvostruki učinak koje to istraživanje ima i na život istraživača i na život sudionika čija je životna priča ispričana. Ona se odnose na propitivanje načina na koje je istraživanje uvijek osobni proces koji na mnoge načine utječe na njihove živote, te je u tom smislu sam proces uvijek refleksivan. O tim se istraživačkim pitanjima raspravlja tijekom cijeloga istraživačkog procesa (Plummer, 2001: 120-121). 


\section{PRIKUPLJANJE I ANALIZIRANJE PODATAKA: PROVEDBA I INSTRUMENTI}

lako je intervjuiranje jedna od češće korištenih tehnika za prikupljanje podataka (Labaree, 2006; Plummer, 2001), ponekad podatci dobiveni intervjuom ne govore dovoljno o "kontekstualiziranom iskustvu pojedinca" (Labaree, 2006) ili ne pružaju razumijevanje struktura koje oblikuju nečiji život (Abu Bakar i Abdullah, 2008). Iz toga proizlazi potreba za primjenom drugih istraživačkih metoda ili analizom dodatnih izvora podataka/dokumenata kao što su pisma, dnevnici, fotografije, osobni dokumenti i sl., intervjuiranja drugih osoba koje mogu pružiti dodatne informacije ili interpretacije, promatranja te usporedbe i reference s drugim istraživačkim projektima (Labaree, 2006; Kouritzin, 2000; Sosulski i dr., 2010; Adriansen, 2012). Intervjui, s druge strane, zahtijevaju pomnu pripremu i proces planiranja. Važan dio toga je i informiranje sudionika o njihovim pravima, pri čemu se kod autora uočava cijeli raspon važnih etičkih aspekata, a koji se odnose na dobrovoljno sudjelovanje (i snimanje intervjua), načelo anonimnosti, povjerljivost (kod potencijalno osjetljivih) informacija, poštovanje privatnosti i dobrobiti sudionika, objašnjenje ciljeva istraživanja te načina prikupljanja i upotrebe/prezentiranja podataka. Istodobno, radi postizanja povjerenja, važnim se ističe i mogućnost postavljanja dodatnih pitanja (tijekom cijeloga istraživačkog procesa) te odustanja u bilo kojem trenutku. $U$ toj se fazi također dogovara i mogućnost davanja transkripata na uvid (Labaree, 2006; Sosulski i dr., 2010; Kouritzin, 2000, Caughey, 2006).

Planirane intervjue moguće je provesti i tijekom nekoliko susreta sa sudionicima. U tom slučaju, prvi susret služi upoznavanju, postizanju informiranog pristanka i stjecanju povjerenja, a svi kasniji susreti predviđeni su za osjetljivija pitanja i/ ili ona vezana uz sam predmet istraživanja. Drugim riječima, prilagođavajući se potrebama i mogućnostima sudionika, možemo utjecati na međusobni odnos i kvalitetu dobivenih podataka (Sosulski i dr., 2010; Haglund, 2004; Caughey, 2006). U kvalitativnim istraživanjima treba se pobrinuti da lokacija na kojoj održavamo intervju pozitivno utječe na ishod istoga. Stoga se savjetuje odabir mirnog i udobnog prostora $^{6}$, ne samo kako bi snimka bila što kvalitetnija i lakša za transkripciju, nego i zato da bi se sami sugovornici osjećali ugodnije (Caughey, 2006; Haglund, 2004). Pozitivne reakcije sudionika proizlaze iz odnosa koji je temeljen na poštovanju, ali i naglašavanjem važnosti njihova sudjelovanja. Od samog početka nužno je biti otvoren i sudionicima objasniti da, zbog svoje prirode, provedba te vrste istraživanja može iziskivati dosta vremena (Caughey, 2006: 27). S druge strane, životna

$6 \quad$ Idealno bi bilo kad bi istraživač bio pozvan u sigurno i ugodno okruženje poput sudionikova doma (Caughey, 2006). Ako to nije moguće, intervju se može dogovoriti negdje gdje bi sudionik u to vrijeme trebao boraviti, čime se prilagođavamo njegovim potrebama (Haglund, 2004). 
povijest pruža i određene koristi samim sudionicima istraživanja kroz mogućnost pričanja svoje priče. Naime, s obzirom na to da su u fokusu najčešće osjetljive teme i svakodnevna osobna iskustva, sugovornici nerijetko osjete zadovoljstvo i olakšanje zbog iskazanog interesa za njihovu priču (Kouritzin, 2000).

$\mathrm{Na}$ ishod provedbe intervjua također mogu utjecati komunikacijske vještine i karakteristike istraživača $s$ obzirom na to da se nove informacije mogu pojaviti u bilo kojem trenutku intervjua. Među važnijima se ističu razvijene tehnike aktivnog slušanja radi dobivanja dubljeg razumijevanje onoga što je rečeno. Istodobno, svojim govorničkim vještinama (pritom ne treba zaboraviti i na važnost neverbalne komunikacije) istraživač stvara povjerljiv i blizak odnos sa sudionicima, čime se umanjuje osjećaj nelagode i potiče na otvaranje, a često uspijeva potaknuti i detaljnije odgovore na postavljena pitanja. Jedna od značajki istraživanja životne povijesti jest izražavanje empatije prema sudionicima i njihovoj priči te poštovanja njihovih osjećaja i mišljenja. Dakle, svojim sveukupnim ponašanjem istraživači jačaju osjećaj dobrobiti, razumijevanja i važnosti (priče) kod sudionika, što zahtijeva i odgovornost prema cjelokupnom istraživačkom procesu (Abu Bakar i Abdullah, 2008; Labaree, 2006; Caughey, 2006; Plummer, 2001). U konačnici, važna je prilagodba istraživača predmetu istraživanja i istraživačkim ciljevima (Caughey, 2006), specifičnim okolnostima (Atkinson, 2002) kao i doživljajima priče(a) od strane sugovornika (Adriansen, 2012). Razmatranja samog okruženja u kojem se intervju provodi ukazuju na metodološka i etička pitanja koja su svojstvena prirodi kvalitativnih istraživanja, a samim time i pristupa životne povijesti.

Planiranje provedbe intervjua uključuje i osmišljavanje istraživačkog protokola (Haglund, 2004; Labaree, 2006). Labaree ističe kako nije svrha razviti sveobuhvatan biografski profil pojedinca i tako prikupiti veliku količinu nepotrebnih informacija, nego je potrebno razviti protokol koji će stvoriti mogućnost što boljeg razumijevanja bitnih trenutaka u životu osobe (Labaree, 2006: 127-128). Drugim riječima, protokol uključuje razradu različitih životnih konteksta koji su ključni u životu osobe (poput škole, obitelji, prijatelja, seksualnosti...), ali i svih ostalih (tema) sukladnih ciljevima istraživanja. Haglund nadalje naglašava kako se (kronološkim) osmišljavanjem pitanja pruža i logički okvir za upravljanje vlastitom pričom (Haglund, 2004: 6). Međutim, važno je da protokol bude fleksibilan s obzirom na "proživljeno iskustvo" ili "jedinstveno iskustvo" sudionika, što može značiti kako su nam često potrebna individualnija pitanja radi dobivanja detaljnog opisa priče ili dubljeg razumijevanja. Stoga je važno biti pripremljen i na različite situacije s obzirom na "izranjajuću" karakteristiku životne povijesti, koja bi mogla zahtijevati osmišljavanje novih, odnosno dodatnih pitanja (Haglund, 2004; Labaree, 2006). Kao što je vidljivo, sama provedba intervjua može predstavljati i svojevrstan izazov istraživačima. Plummer napominje kako se intervju može "kretati" na kontinuumu od pozitivističkog do in- 
terpretativističkog, dok je on ipak skloniji otvorenom, aktivnom, interaktivnom tipu intervjua s tek općenitijim smjernicama (Plummer, 2001: 140-141). Tako primjerice i Wengraf (2001) problematizira metodu intervjua i detaljno razmatra primjenu biografsko-narativnog intervjua s minimalnim upletanjem istraživača u odnosu na polustrukturirani dubinski intervju.

Unatoč pretpostavci da je prije početka samog intervjua uspostavljen blizak i povjerljiv odnos, Caughey savjetuje kako je dobro započeti intervju razgovorom radije nego formalnim pitanjima, pri čemu nakon svakog pitanja sudionicima treba dati dovoljno vremena za razmišljanje i odgovaranje. Tako se umanjuje i moguća nelagoda kod sudionika. $U$ istraživanjima životnih povijesti uobičajeno je započeti širim pogledom na živote sudionika te postupno sužavati (njihovu) priču prema području istraživačkog interesa. Također, produktivnim se smatra poticanje sudionika na davanje primjera ili nastavak priče koja može biti ključna za istraživanje s obzirom na to da se često događa da sudionici daju vrlo kratke i općenite odgovore (Caughey, 2006: 34-35). Postavljanjem otvorenih pitanja istraživač može zabilježiti detaljne informacije o različitim periodima u životu sudionika, društvenom i ekonomskom kontekstu te bolje razumjeti ponašanja, događaje, odnose i različite životne okolnosti (Abu Bakar i Abdullah, 2008). Caughey također ističe važnost otvoreni(ji)h pitanja koja sudionike potiču na pričanje iz vlastite perspektive, ali i "subjektivnu organizaciju" osobne povijesti (Caughey, 2006: 28). Na tragu tih razmišljanja uočavamo kako otvorenim pitanjima kreiramo i vlastite smjernice s kojima (uz istraživački protokol) aktivno osmišljavamo dodatna pitanja i oblikujemo nastavak intervjua. ${ }^{7}$ Pritom mogu biti korisne i određene tehnike tijekom intervjuiranja, kao što je tehnika lijevka. ${ }^{8}$

Neke od specifičnosti pristupa životne povijesti leže u mogućnostima korištenja različitih tehnika, odnosno instrumenata čiji odabir može ovisiti o istraživačkim ciljevima (Adriansen, 2012). Jedan je od takvih instrumenata vremenska ili životna linija (eng. timeline/lifeline) koja se opisuje kao vizualni prikaz ključnih životnih događaja kronološkim redom i način angažiranja sudionika u konstrukciju priče (Adriansen, 2012; Berends, 2011; Gramling i Carr, 2004). Ta tehnika omogućuje da se događaji i njihovo viđenje/značenje sagledaju unutar konteksta "životnog iskustva". Tehnički gledano, vremenska ili životna linije sudionicima se prezentira kroz kratki opis, objašnjenje njezine svrhe i način na koji će se koristiti. Za izradu se najčešće koristi veliki komad papira i olovke/flomasteri u različitim bojama (kojima se tijekom

7 Odluka o tome je li fokus na načinu na koji je priča ispričana (životna priča) ili njezina povezanost s kontekstom (životna povijest) može utjecati i na samu provedbu intervjua. Drugim riječima, o tome ovisi hoće li istraživač ići prema (ne)strukturiranom pristupu postavljanja pitanja ... ali i načinu korištenja ostalih instrumenata (Adriansen, 2012).

8 Više o tim tehnikama vidjeti kod Plummer (2001). 
intervjua ili kasnije u analizi dodaje kontekst, odnosno informacije o bitnim društvenim/političkim događajima). Istraživač može, na samom početku, dužinom ili širinom papira povući liniju (može in biti i više, upravo zbog važnosti različitih konteksta za priču) koja prikazuje bitne događaje u životu sudionika, moguća objašnjenja istih, ali i njihova međusobna povezanost (Adriansen, 2012: 43-44). Kako bismo potaknuli kreativni angažman i demonstrirali ključni aspekt fleksibilnosti pri izradi istoga, preporučuje se sudionicima pokazati nekoliko različitih primjera. $\mathrm{Ne}$ postoji pravilo kako u konačnici treba izgledati, pri čemu vremenska linija može biti u različitim oblicima: linijama, krivuljama i sl. (Kolar i dr., 2015: 18). Sudionicima se, dakle, može pružiti prazan list papira na kojem sami odabiru stil vremenske linije (Adriansen, 2012), pri čemu se uočavaju i različiti načini njezina korištenja/ispunjavanja od strane sudionika, odnosno na početku ili tijekom intervjua (Kolar i dr., 2015; Adriansen, 2012). Što predstavlja početak, a što kraj vremenske linije ovisi o predmetu istraživanja sukladno kojem se odabire prvi ključan trenutak u životu. Ako sudionik smatra relevantnim, vremenska linija može završavati i prikazom očekivanih događanja u budućnosti (Adriansen, 2012; Kolar i dr., 2015).

Instrumenti mogu biti i u obliku životno-povijesnih tabličnih prikaza (eng. life history grid), koji se u istraživanju koristi radi sažetog i vizualnog organiziranja događaja i povezivanja dijelova životne povijesti. Svrha je njegova konstruiranja određivanje obrazaca radi razumijevanja priča koje sudionici pričaju o svome životu. U izradi se također koristi veliki list papira koji se podijeli na stupce predviđene za različite teme, odnosno obrasce ponašanja (kao što su obitelj, mjesto stanovanja, prijatelji, škola, aktivnosti, ljubavne veze i sl.), dok se s lijeve strane navođenjem vremenskog razdoblja priči daje kronološki aspekt (Haglund, 2004: 8-9). Jedan od načina korištenja životno-povijesnog tabličnog prikaza na koji Haglund ukazuje, pozivajući se na istraživanja drugih, jest tijekom intervjua kao način angažiranja i uključivanja sudionika. S druge strane, ako oduzima previše vremena i skreće pozornost, može se ispunjavati tijekom preslušavanja snimki intervjua, čime se olakšava analiza podataka (Haglund, 2004). U literaturi se navodi i životno-povijesni kalendar (eng. life history calendar) koji je kompleksniji i spaja niz različitih povijesnih događaja te je, grafički gledano, adekvantniji u prikupljanju retrospektivnih podataka. Opisuje se u formatu velike tablice gdje su s jedne strane obrasci ponašanja koji se istražuju kroz različite životne periode i kategorije interesa, a s druge strane vremenske jedinice (dani, tjedni, mjeseci, godine) koje ovise o potrebi istraživanja. To bi sudioniku moglo pomoći da vizualno i mentalno poveže vremenske periode s različitim događajima u životu (Freedman i dr., 1988).

U svrhu što smislenije i pouzdanije analize, interpretacije i prezentiranja podataka važna je organizacija i upravljanje dobivenim podatcima (Labaree, 2006). Kouritzin smatra kako je upravo opsežnost jedna od prednosti pristupa životne 
povijesti, jer omogućuje istraživaču i drugima da na različite načine i u različitim vremenima interpretiraju životne priče na tragu razvijanja novih teorija i stjecanja novih spoznaja (Kouritzin, 2000: 14). ${ }^{9}$ Jedan je od koraka u analizi i transkripcija podataka, pri čemu je ponekad potrebno nekoliko puta preslušati snimke i iščitati transkripte zbog pojavljivanja ideja i isticanja ključnih tema (Labaree, 2006). S druge strane, Caughey upućuje i na važnost reflektiranja na intervju(e) netom nakon provedbe pišući bilješke sa strane za vrijeme transkripcije (Caughey, 2006: 39). Čitajući iste i obraćajući pozornost na to kako se sudionik osjeća i razmišlja, kako se izražava, povećava se mogućnost dubljeg razumijevanja izjava koje na prvu možda ne otkrivaju mnogo. Osim toga, sva zabilježena zapažanja tijekom i nakon intervjua mogu mnogo toga otkriti o kvaliteti dobivenih podataka i uspostavljenom međusobnom odnosu. S obzirom na to da je životno-povijesni intervju često vrlo osoban susret istraživača i sudionika, a analiza subjektivna, Atkinson ističe kako je osnovni cilj transkripcije osigurati točnost značenja riječima sudionika. Ponekad upravo izvorna uporaba jezičnih fraza, dijalekt i druge verbalne posebnosti mogu imati veliku ulogu u interpretaciji podataka. No, treba napomenuti kako se transkripciji može pristupiti na različite načine, ovisno o istraživačkim ciljevima (Atkinson, 2002, 133-134).

Važnost procesa analiziranja i interpretiranja podataka ističu, dakako, i brojni drugi autori, pri čemu Caughey naglašava kako je cilj razumijevanje nečijih stajališta. To se razumijevanje postiže reflektiranjem na vlastite obrasce razmišljanja koje se postiže promišljanjem vlastitih stajališta (istraživača) u svrhu razumijevanja stajališta sugovornika (Caughey, 2006: 41). Drugim riječima, s obzirom na svoju kvalitativnu prirodu, pristup životne povijesti temelji se na refleksivnim načinima primjene i analize podataka. S druge strane, ovisno o predmetu istraživanja i istraživačkom dizajnu, različite su strategije i pristupi u analizi životno-povijesnih podataka (Adriansen, 2012). lako je analizu moguće provesti s pomoću prethodno definiranih kodova, u kvalitativnim istraživanjima ona najčešće započinje reduciranjem teksta u smislene analitičke kategorije tako da se kodovi pojavljuju tijekom proučavanja samoga teksta (induktivni pristup) ${ }^{10}$. Krajnji je analitički korak organizi-

9 U svom radi autorica upućuje i na teorijske doprinose pristupa životne povijesti u vidu proširivanja, revidiranja pa i odbacivanja postojećih teorija zbog mnoštva i raznolikosti podataka koji se prikupljaju. Pritom Kouritzin spominje kako životna povijest omogućuje analizu individualnih aspekata (npr. osobnosti, motivacije i sl.), grupnih i kolektivnih (npr. obiteljskih odnosa i vrijednosti, odnosa u školi) ali i društvenih (npr. imigracija, kulturni šok) (Kouritzin, 2000: 15). Drugim riječima, mogućnosti zahvaćanja više razina interpretacije pridonose boljem razumijevanju istraživanog fenomena.

10 Kolar i suradnici (2015) su za potrebe vlastitog istraživanja u analizi, osim transkripta intervjua, tematski kodirali i vremenske linije, odnosno njihov sadržaj i oblik kako bi istražili ulogu istoga u boljem razumijevanju iskustava sudionika. Osim istraživača, u analizu su uključili i vanjske suradnike koji nisu sudjelovali u procesu prikupljanja podataka. 
ranje kodova u šire konceptualne kategorije koje ukazuju na potencijalne sličnosti, razlike, obrasce i strukture istraživanog fenomena (Labaree, 2006: 130).

Međutim, analiza(e) životnih povijesti mogu se sagledati i unutar paradigmatskih okvira što nameće različite teorijsko-metodološke postavke. U biografskim istraživanjima prepoznaju se dvije temeljne perspektive: realista i neopozitivista te ona "narativista", koji zauzimaju interpretativistički pristup stvarnosti. Osnovne su analitičke razlike u pristupu biografijama i životnoj povijesti, pri čemu realisti i neopozitivisti teže razvijanju i testiranju teorije. Narativna analiza stavlja naglasak na konstrukciju životne priče unutar konteksta samog intervjua i prikupljanje životne povijesti (Miller, 2003: 16). Kod interpretativista životne priče i životne povijesti mogu predstavljati i različite analitičke koncepte (Miller, 2003; Rosenthal, 2004). Rosenthal (1993, 2004, 2006) iz perspektive biografske istraživačice i sociologinje koristi upravo takav analitički koncept, pri čemu kao instrument koristi biografsko-narativne intervjue. Rosenthal (1993) analizira životne povijesti iz usmenih biografskih prezentacija svojih sugovornika ispričanih u formi rekonstruiranih životnih priča. Drugim riječima, istraživačica interpretira značenja koja se pridaju fenomenima unutar konteksta nečije biografije te ističe kako je kod rekonstrukcije životne prošlosti, koja se prikazuje u sadašnjosti životnih priča, nužno uzeti u obzir da se prikazivanje odvija u trenutcima govorenja o istima (Rosenthal, 2004: 49-50). Rosenthal navodi nekoliko koraka u analizi, pri čemu razlikuje dvije razine: analizu proživljene životne povijesti (rekonstrukcija biografskih značenja iskustava sudionika u trenutku kad su se zbili) i analizu ispričane životne priče (rekonstrukcija vremenskog slijeda i trenutačnih značenja koja sudionik pridaje vlastitim životnim iskustvima) (Rosenthal, 1993: 2). U konačnici, cilj je biografskog istraživanja rekonstruiranje odnosa između individualnog iskustva i društvenog okvira (Rosenthal, 2004: 62).

Pristup životne povijesti u Hrvatskoj ne pronalazi svoje mjesto u metodološkim raspravama, a kao polazište samo u rijetkim teorijskim i istraživačkim radovima u području društvenih znanosti i/ili sociologije. Jedan od tih radova jesu i (narativna) istraživanja iskustava znanstvenica tijekom njihove profesionalne socijalizacije (Brajdić Vuković, 2017; Brajdić Vuković i Vignjević, 2017). Analiza narativnih intervjua provedena je strukturalnom organizacijom (individualnih) narativa ${ }^{11} \mathrm{~s}$ ciljem njihove usporedbe te razumijevanja i sagledavanja životnih priča iz različitih perspektiva (Brajdić, 2017; Brajdić Vuković i Vignjević, 2017). Životne se priče sagledavaju kroz individualna iskustva u određenom kontekstu, pri čemu se ističe kako upravo narativna analiza omogućuje interpretaciju značenja dobivenih iz tih životnih priča (Brajdić Vuković i Vignjević, 2017). Provedena narativna analiza ov-

11 Riječ je o tzv. Labovljevom strukturalnom modelu narativne analize, o kojemu Brajdić Vuković (2017) te Brajdić Vuković i Vignjević (2017) pišu detaljnije. 
dje je obuhvatila tri razine: makrorazinu, mezoorganizacijsku razinu i mikroosobnu razinu profesionalne socijalizacije znanstvenica s ciljem otkrivanja značenja koja se pridaju društveno konstruiranom fenomenu (Brajdić Vuković, 2017; Brajdić Vuković i Vignjević, 2017). Korištenje životne povijesti u sociološkim se istraživanjima dodatno obrazlaže individualnim promišljanjima stvarnosti (Lalić, 1995).

Kouritzin (2000) ističe kako životna povijest predstavlja više od tehničkog prikupljanja podataka i narativnog prikaza individualnih ili kolektivnih životnih priča. Njezine su mogućnosti i u kritičkoj interpretativnoj analizi, pri čemu se bolje razumijevanje životne povijesti postiže ukoliko se sagleda kao poseban tip analize slučaja. Pritom, s druge strane, autorica smatra važnim istaknuti i njihove razlike u definiranju konteksta, davanju prednosti individualnim razumijevanjima fenomena i sl. No, kao i kod analize slučaja, naglasak se stavlja na analizu, triangulaciju, kompleksnost i tekstualni prikaz. U tom smislu, pristup životne povijesti koristi: usmeni prikaz života sudionika, podatke iz intervjua u svrhu razumijevanja, dodatne dokumente o događajima, dodatne intervjue zbog mogućih alternativnih interpretacija, usporedbe s drugim istraživanjima i analize i usporedbe s različitim izvorima (Kouritzin, 2000: 3-4). Drugim riječima, životna povijest koristi se unutar različitih istraživačkih strategija (narativnog istraživanja, biografskog istraživanja, analize slučaja...), gdje istraživači zauzimaju i određene pozicije u/prema životnim povijestima/ životnim pričama. To dodatno ukazuje na njezinu specifičnost u bavljenju različitim teorijskim i metodološkim pitanjima (Bertaux, Kohli, 1984). S druge strane, istraživanja ne moraju nužno imati životnu povijest kao polazište. Tako se, primjerice, u istraživanju profesionalnih biografija (žena) polazi od feminističke teorije stajališta, ali se ukazuje na "narativne odsječke" i "biografske trenutke" u intervjuima (Barada, 2013), pri čemu rad također smatramo doprinosom metodološkim i etičkim raspravama o kvalitativnim pristupima općenito.

\section{PRIKAZIVANJE PODATAKA: METODOLOŠKA I ETIČKA PITANJA}

S obzirom na prirodu kvalitativnog istraživanja, istraživačima nije lako predvidjeti kako će priče biti interpretirane od strane drugih (Kouritzin, 2000). Labaree (2006) stoga naglašava kako je nužno isplanirati način na koji će životna povijest biti prikazana. Jedan od mogućih pristupa prikazivanju podataka koje navodi jest prezentiranje svake priče kao posebnog slučaja, pri čemu se podcrtavaju ključna pitanja koja su se pojavila tijekom analize. Na taj se način ističe posebnost individualnih iskustava. Drugim pristupom rezultati se prezentiraju sukladno izranjajućim temama, koje su praćene citatima iz intervjua (i moguće drugih izvora). Specifičnost je tog pristupa u opisivanju ključnih tema koje su proizišle iz podataka, jer se tako 
individualna iskustva mogu povezati s određenim problemima ili pretpostavkama i time utjecati na javne politike (Labaree, 2006, 130). ${ }^{12} U$ toj je fazi nužno ukazati na moguće pristranosti koje istraživač ima u vezi istraživanja i rezultata. Time se, naglašava Labaree, povećava vjerodostojnost podataka i pomaže čitatelju u razumijevanju interpretativnog procesa. Izazov kod objavljivanja životne povijesti jest u razvijanju priče koja ističe glasove sudionika, ali koja istodobno uključuje i istraživača kao instrument u analizi i interpretaciji (Labaree, 2006, 131). Pritom se, dakle, podcrtava uloga istraživača s obzirom na to da razumijevanje društvene konstrukcije priča uključuje pomak prema kontekstu koji se smatra važnim korakom u interpretativnoj fazi životne povijesti. Taj pomak od životne priče prema životnoj povijesti Goodson opisuje kao "opasan pomak", jer on zapravo daje istraživaču autoritet da smjesti nečiju priču (Goodson, 2001: 139).

Polazeći od uloge istraživača u tekstu, naglasak se stavlja na trenutak kad istraživač postaje interpretator (Labaree, 2006) ili autor (Tierney, 1998), što može imati različite implikacije. Naime, životna povijest zahtijeva određeni stupanj autorske zastupljenosti s obzirom na to da je riječ o ko-konstrukciji priče između istraživača i sudionika (Adriansen, 2012; Labaree, 2006; Tierney, 1998, 2013; Kouritzin, 2000), kao i kod većine kvalitativnih pristupa. S druge strane, kao istraživači ne možemo zanemariti činjenicu da $u$ istraživačke interakcije unosimo dio vlastite osobnosti i način ophođenja prema drugima (Tierney, 1998: 52). Istodobno, Labaree razmatra kako subjektivna, promjenjiva i multidimenzionalna konstrukcija stvarnosti istraživačima predstavlja izazov. Naime, kako bi istraživanje bilo valjano, čitatelj treba imati povjerenja u ono što se prikazuje, a to je "stvarnost" nečijega životnog iskustva. Međutim, cilj nije postići potpunu objektivnost, nego opisati potencijalne pristranosti na način koji dopušta čitatelju da odredi kako te pristranosti mogu utjecati na interpretaciju rezultata (Labaree, 2006: 134-135). Kouritzin ističe kako kod pristupa životne povijesti pitanje objektivnosti i subjektivnosti poprima nove dimenzije s obzirom na to da se od istraživača ovdje traži privržen odnos sa sudionicima radi njihove osobne dobrobiti (Kouritzin, 2000: 29). U kvalitativnim istraživanjima pristranosti se ne mogu u potpunosti ukloniti, jer se mogu pojaviti pod utjecajem sudionika, istraživača ili kao rezultat njihove interakcije (Plummer, 2001: 155-156). Međutim, način ophođenja prema istima može utjecati na kvalitetu rezultata istraživanja (Labaree, 2006; Plummer, 2001). ${ }^{13}$

12 Ojermark (2007) dodatno ističe kako istraživači svoje podatke prikazuju na način koji odgovara poziciji koju zauzimaju, bilo da je riječ o realističkoj ili konstruktivističkoj. U tom pogledu ukazuje na to da narativna analiza stavlja fokus na individualnim iskustvima i konstrukciji značenja, dok fokus na javnim politikama polazi od realističke perspektive koja naglašava kako životne priče odražavaju objektivnu stvarnosti. No, autorica uočava i određena preklapanja u pristupima.

13 Pritom mogu pomoći i određeni načini provjere valjanosti o kojima više piše Plummer (2001). 
Konvencionalna priča o vrednovanju istraživanja temelji se na pitanjima valjanosti, pouzdanosti, reprezentativnosti/generalizabilnosti... na koja, u većoj ili manjoj mjeri, pokušava odgovoriti i pristup životne povijesti (Abu Bakar i Abdullah, 2008; Dyson, 2003; Goodson, 2001; Kouritzin, 2000; Ojermark, 2007; Plummer, 1990, 2001; Labaree, 2006; Atkinson, 2002). Ovdje se kratko zadržavamo na Plummerovim (2001) razmatranjima jer on smatra kako primjena tih kriterija na istraživanje životnih priča/životnih povijesti možda ipak nije adekvatna. Plummer tako koristi termin "kontinuum reprezentativnosti" kako bi ukazao na to da priče mogu varirati od toga budu "tipične" (za širu populaciju) do toga da prikazuju "jedinstveno iskustvo". S druge strane, pozivajući se na Blumera, drži kako je moguć i srednji put (između tih ekstrema), a to je odabir ključnih informanata (eng. key informants) koji mogu pružiti razumijevanje određenog načina života (Plummer, 2001: 153-154). Nadalje, ne propitujući pouzdanost, zbog prirode životne povijesti i "subjektivne priče" koju istraživač zapravo i želi dobiti (Plummer, 2001: 155), zadržava se na izvorima pristranosti i pitanjima valjanosti. Ulogu istraživača u procesima interpretiranja i pisanja, Plummer sažima kroz dvije koncepcije: "kontinuum konstrukcije" (interpretacije) između sudionika i istraživača te "demokratske tekstove" u kojima se odvija fluidnost glasova (Plummer, 2001).

Dyson također pristupa pitanju valjanost kao jednoj od važnih metodoloških odrednica životne povijesti, koja i po njegovim uvidima može biti pod utjecajem sudionika, istraživača i/li njihove interakcije tijekom konstrukcije nečije subjektivne priče, pri čemu su i za Dysona one u fokusu sociološkog interesa i primjene tog pristupa (Dyson, 2003: 97-98). S druge strane, naglasak na prirodu interaktivnog odnosa u kvalitativnim pristupima potiče na daljna razmatranja etičkih pitanja - bilo da je riječ o etičkim principima anonimnosti, privatnosti i sl., ili pak nekim više specifičnim pitanjima pristupa životne povijesti (poput odnosa moći, prava vlasništva...). Kako se u radovima uočava širi raspon mogućih etičkih pitanja, zaključujemo da ta pitanja mogu biti usko vezana i za posebnost neke istraživačke teme. Adriansen (2012), Kouritzin (2000) i Labaree (2006) tako ističu važnost uspostavljanja povjerenja tijekom provođenja intervjua s obzirom na osobnu i intimnu prirodu odnosa između istraživača i sudionika ${ }^{14}$. Ovdje se, posljedično, isprepleću etički i metodološki aspekti životne povijesti. Naime, različite korištene tehnike (prethodno opisane) tijekom provođenja intervjua pomažu uspostavi povjerenja i tako postaju ključan dio etičkih razmatranja, pri čemu Andriansen sugerira kako se taj dio zbog anonimnosti i povjerljivih informacija ipak ne bi trebao objavljivati (Adriansen, 2012: 46-47), što je više metodološko pitanje. Ovime, dakle, želimo pokazati kako etička

14 Uloga istraživača, međutim, može varirati od one insidera do outsidera, što može imati implikacije na (najšire rečeno) proces uspostavljanja povjerenja i odnosa sa sudionicima tijekom i nakon istraživanja, o čemu više piše Labaree (2006). 
pitanja kod pristupa životne povijesti postaju i važan dio njegovih metodoloških razmatranja.

Nadalje, te specifičnosti životne povijesti (odnosno korištene tehnike prilikom intervjuiranja) sudionicima omogućuju preuzimanje vlasništva nad (tako) provedenim intervjuom te djelomično i preuzimanje kontrole tijekom samog procesa intervjuiranja, ističe Andriansen. Za razliku, dakle, od bilješki istraživača, tehnike za provođenje životne povijesti smatraju se i vlasništvom sudionika (Adriansen, 2012: 48). Autori dodatno ističu kako sudionici istraživanja zapravo imaju pravo na kopiju grafičkih ili tabličnih prikaza (Adriansen, 2012; Haglund, 2004), ovisno o tome što se $u$ istraživanju koristilo. S druge strane, iako istraživač ima autoritet (eng. analytical power) u bitnim metodološkim odlukama (kod odabira sudionika i prikladnosti spomenutih tehnika za provođenje intervjua), sudionici su (zahvaljujući specifičnostima tehnika provedbe životno-povijesnog intervjua) oni koji intervju vode u određenom smjeru ključnih pitanja i događaja. Sve spomenuto dovodi i do promjene u (konvencionalno definiranim) odnosima moći između istraživača i sudionika (Adriansen, 2012: 48-49). Kao što je već istaknuto, životna povijest donosi subjektivne priče, pri čemu Dyson uspostavljeni odnos tijekom intervjuiranja podvlači i pod pitanje valjanosti socioloških podataka. Naime, tijekom intervjua sudionici na temelju vlastitih shvaćanja što se od njih traži odlučuju koju će priču ${ }^{15}$ ispričati, a što se povezuje s (različitim) doživljajima istraživačevog autoriteta i kontrole te upućuje na kompleksne i intertekstualne odnose kod pojedinih priča (Dyson, 2003: 97-99).

\section{ZAKLJUČAK: PERSPEKTIVE ŽIVOTNE POVIJESTI}

Na tragu metodološke literature o životnoj povijesti nailazimo na različite perspektive koje okružuju taj pristup, što dovodi do zaključka kako se njegovim teorijskim, metodološkim i istraživačkim aspektima treba pristupiti imajući na umu odluke istraživača o svrsi njegova korištenja. Ukoliko želimo izbjeći neiscrpne (po našem mišljenju i nepotrebne) rasprave o kvantitativnim i kvalitativnim istraživačkim pristupima, onda se kao istraživači nalazimo u situaciji da pristup životne povijesti razmatramo kroz njegove specifičnosti. Drugim riječima, neke od pretpostavki od koje polazimo jesu da pristup životne povijesti ide prema prihvaćanju onih tendencija u suvremenoj sociologiji koje dovode u pitanje konvencionalno usmjerene odnose prema objektivnosti, subjektivnosti, "istini”, ulozi istraživača, kriterijima valjanosti, etičnosti i sl., a samim time i prema pluralizmu u sociološkoj metodologiji. Nadalje, pozicija (bilo ona konstruktivistička, realistička...) s koje kao istraživači krećemo također se smatra bitnom metodološkom odrednicom kako u korištenju

15 O razlici između “javnih" i "privatnih” priča vidjeti kod Dyson (2003). 
ostalih pristupa tako i kod životne povijesti, s obzirom na to da ona usmjerava odluke koje donosimo tijekom istraživačkog procesa. Ovdje je nužno naglasiti kako ne propagiramo tezu da sve može proći (eng. anything goes), nego odnos prema istraživačkim pristupima u suvremenoj sociološkoj metodologiji koji prihvaća njihove metodološke i istraživačke značajke. Prema zapažanjima suvremenih autora, kvalitativni pristupi naglašavaju potrebu za (postmodernističkim) tendencijama u sociološkoj metodologiji koje dovode u pitanje (modernistička) naglašavanja objektivnosti, formuliranja hipoteza, generaliziranja i izgradnje apstraktnih teorija, pa i načine pisanja.

Analiza radova na temu pristupa životne povijesti ukazuje ponajprije na njegovu primjenu u istraživanju raznolikih društvenih fenomena. U prvom se redu uočava iznimna pogodnost u istraživanju i razumijevanju problema specifičnih, manjinskih i marginaliziranih skupina čiji se glasovi mogu čuti upravo kroz pričanje priča i njihovih vlastitih životnih povijesti s obzirom na značajnu spremnost članova tih skupina na iznošenje vlastitih iskustava. Time se omogućuje ne samo analiza individualnih obilježja i pojedinačnih slučajeva, nego i grupnih vrijednosti i kolektivnih djelovanja. Nadalje, s obzirom na to da životna povijest nudi više od životne priče, jer iako je i ona sama po sebi konstrukcija, obuhvaća šaroliku lepezu kontekstualnih i povijesnih informacija, što nam omogućuje i istraživanje načina na koje društvene strukture (politike, obrazovne institucije...) i društvene promjene utječu na oblikovanje životnih priča i konstrukciju priča u sadašnjosti. Drugim riječima, pristup životne povijesti moguće je koristiti za istraživanje i analizu fenomena na svim razinama (mikro, mezo i makro). Ujedno tako, istraživanja pokazuju cijeli niz metodoloških prednosti koje nudi taj pristup, počevši od bogatstva podataka i različitih načina njihova prikazivanja, smanjenog utjecaja istraživača koji se postiže različitim tehnikama i razinama analize koje se koriste, itd.

U konačnici, način na koji ćemo koristiti životnu povijest ovisi ponajprije o predmetu i ciljevima našeg istraživanja kao i načinu na koji ćemo životnu povijest staviti u centar svoga istraživačkog interesa (hoćemo li je koristiti kao pristup, metodu, objekt ili temu istraživanja). Stoga ne postoji sveobuhvatni obrazac kako primjenjivati pristup ili metodu životne povijesti, pri čemu on i nije nužan. Sve učestalijom primjenom životnih povijesti zapravo otkrivamo raznolikost načina na koje istraživači kombiniraju različite i teorijske i metodološke pristupe i orijentacije (simbolički interpretativizam, fenomenologiju, etnografiju, strukturalizam...) s pristupom životne povijest koristeći pritom njegove višestruke prednosti, razvijajući raznolike prakse (primjerice, uzorkovanja, prikupljanja i analiziranja podataka, postizanja valjanosti, rješavanja problema objektivnosti/subjektivnosti...) akumulirajući pritom znanja i vještine te rješavajući i razmatrajući i neke nedostatke koji se pritom pojavljuju. 


\section{LITERATURA}

Adriansen HK (2012). Timeline Interviews: A Tool for Conducting Life History Research, Qualitative Studies, 3 (1): 40-55. https://doi.org/10.7146/qs.v3i1.6272

Abu Bakar NR i Abdullah MY (2008). The Life History Approach: Fieldwork Experience, Journal e-Bangi, 3 (1): 1-9. https://www.researchgate.net/publication/245584554_The_ Life_History_Approach_Fieldwork_Experience (18. travnja 2019.)

Atkinson R (2002). The Life Story Interview. U: Gubrium JF i Holstein JA (ur.). Handbook of Interview Research: Context \& Method. Thousand Oaks, London, New Delhi: Sage Publications, 121-140.

Barada V (2013). Primjena feminističke teorije stajališta u istraživanju ženskih profesionalnih biografija, Revija za sociologiju, 43 (3): 199-222. https://doi.org/10.5613/rzs.43.3.1

Berends L (2011). Embracing the Visual: Using Timelines with In-depth In Interviews on Substance Use and Treatment, The Qualitative Report, 16 (1): 1-9.

Bertaux D i Kohli M (1984). The Life Story Approach: A Continental View, Annual Review of Sociology, 10: 215-237. https://doi.org/10.1146/annurev.so.10.080184.001243

Brajdić Vuković M (2017). "I, što se onda dogodilo?": Ključni događaji, želje, strahovi, spoznaje i obrati u narativima o iskustvu profesionalne socijalizacije mladih znanstvenika. U: Ledić J i Brajdić Vuković M (ur.). Narativi o profesionalnoj socijalizaciji mladih znanstvenika. Rijeka: Filozofski fakultet Sveučilišta u Rijeci, 73-96.

Brajdić Vuković M i Vignjević B (2017). "I mean, that amount of work would consume me at one point": The Narrative of the Life History of Young Researchers During the Professional Socialisation Into the Teaching And Research Profession in the Croatian Higher Education System. U: Ledić J i Turk M (ur.). Teaching and Research in the Professional Socialization of Junior Researchers. Rijeka: Faculty of Humanities and Social Sciences University of Rijeka, 113-150.

Caughey JL (2006). Negotiating Cultures \& Identities: Life History Issues, Methods and Readings. Lincoln: University of Nebraska Press.

Dhunpath R (2000). Life History Methodology: 'Narradigm' Regained, International Journal of Qualitative Studies in Education, 13 (5): 543-551. https://doi. org/10.1080/09518390050156459

Dyson S (2003). Life Histories: Interpreting the Subjective Reality Studying Nursing in UK. U: Horrocks C, Kelly N, Roberts B i Robinson D (ur.). Narrative, Memory and Health. Huddersfield: University of Huddersfield, 97-104.

Freedman D, Thornton A, Camburn D, Alwin D i Young-DeMarco L (1988). The Life History Calendar: A Technique for Collecting Retrospective Data, Sociological Methodology, 18: 37-68. https://doi.org/10.2307/271044

Gramling LF i Carr RL (2004). Lifelines - A Life History Methodology, Nursing Research, 53 (3): 207-210. https://doi.org/10.1097/00006199-200405000-00008

Goodson I (2001). The Story of Life History: Origins of the Life History Method in Sociology, Identity: An International Journal of theory and Research, 1 (2): 129-142. https://doi. org/10.1207/S1532706XID0102_02

Haglund K (2004). Conducting Life History Research with Adolescents, Qualitative Health Research, 14 (9): 1309-1319. https://doi.org/10.1177/1049732304268628 
Kolar K, Ahmad F, Chan L i Erickson PG (2015). Timeline Mapping in Qualitative Interviews: A Study of Resilience with Marginalized Groups, International Journal of Qualitative Methods, 14 (3): 13-32. https://doi.org/10.1177/160940691501400302

Kouritzin SG (2000). Bringing Life to Research: Life History and ESL, TESL Canada Journal, 17 (2): 1-35. https://doi.org/10.18806/tesl.v17i2.887

Labaree RV (2006). Encounters with the Library: Understanding Experience Using the Life History Method, Library Trends, 55 (1): 121-139. https://doi.org/10.1353/lib.2006.0048

Lalić D (1995). Ekonomska reprodukcija ovisnosti o heroinu - Split devedesetih godina, Revija za sociologiju, 26 (3-4): 209-218.

Lončar M (2010). Novi metodološki žanr u sociologiji: postmoderno istraživanje. Split: Redak.

Miller R (2003). Biographical Method. U: Miller R i Brewer JD (ur.). The A-Z of Social Research. A Dictionary of Key Social Science Research Concepts. London, Thousand Oaks, New Delhi: SAGE Publications, 15-17.

Ojermark A (2007). Presenting Life Histories: A literature review and annotated bibliography, Working Paper No. 101. United Kingdom: Chronic Poverty Research Centre. http://www. chronicpoverty.org/uploads/publication_files/WP101_Ojermark.pdf (18. travnja 2019.)

Plummer K (1990). Herbert Blumer and the Life History Tradition, Symbolic Interaction, 13 (2): 125-144.

Plummer K (2001). Documents of Life 2. An Invitation to a Critical Humanism. Second Edition. London, Thousand Oaks, New Delhi: SAGE Publications.

River J i Fisher MJ (2015) Theorized Life Histories: Masculinity and Male Suicide. U: de Chesnay M (ur.). Nursing Research Using Life History: Qualitative Designs and Methods in Nursing. New York, USA: Springer Publishing Company, 155-168.

Rosenthal G (1993). Reconstruction of Life Stories: Principles of Selection In Generating Stories For Narrative Biographical Interviews, The Narrative Study of Lives, 1 (1): 59-91.

Rosenthal G (2004). Biographical Research. U: Seale C, Gobo G, Gubrium JF i Silverman D (ur.). Qualitatative Research Practice. Los Angeles, London, New Delhi, Singapore: SAGE Publications, 48-64.

Rosenthal G (2006). The Narrated Life Story: On the Interrelation Between Experience, Memory and Narration. U: Milnes K, Horrocks C, Kell N, Roberts B i Robinso D (ur.). Narrative, Memory \& Knowledge: Representations, Aesthetics, Contexts. Huddersfield: University of Huddersfield, 1-16.

Sosulski MR, Buchanan NT i Donnell CM (2010). Life History and Narrative Analysis: Feminist Methodologies Contextualizing Black Women's Experiences with Severe Mental IIIness, The Journal of Sociology \& Social Welfare, 37 (3): 29-57.

Tierney WG (1998). Life History's History: Subjects Foretold, Qualitative Inquiry, 4 (1): 4970. https://doi.org/10.1177/107780049800400104

Tierney WG (2013). Life History and Identity, The Review of Higher Education, 36 (2): 255282. https://doi.org/10.1353/rhe.2013.0006

Wengraf T (2001). Qualitative Research Interviewing: Biographic Narrative and SemiStructured Methods. London, Thousand Oaks, New Delhi: Sage Publications.

Wengraf T (2000). Uncovering the General from Within the Particular: From Contingencies to Typologies in the Understanding of Cases. U: Chamberlayne P, Bornat Y i Wengraf T (ur.). The Turn to Biographical Metods in Social Science. Comparative Issues and Examples. London, New York: Routledge, 140-164. 


\title{
Theoretical and Methodological Aspects of Life History Approach in Sociology
}

\author{
Marija LONČAR \\ Faculty of Humanities and Social Sciences, University of Split, Croatia \\ marija.loncar@ffst.hr \\ Zorana ŠULJUG VUČICA \\ Faculty of Humanities and Social Sciences, University of Split, Croatia \\ zorana@ffst.hr \\ Tea BUBIĆ \\ DOMINE - Organization for promoting women's rights, Croatia \\ bubic.tea@gmail.com
}

\section{ABSTRACT}

Although for a long time many researchers tended to focus on quantitative methods and statistical procedures, as well as certain qualitative methods and data sources, over the past years numerous authors have been talking about a growing interest in the life history approach. Its significant beginnings are noted in sociology. Nevertheless, the field of sociology in Croatia still shows no significant interest in the theoretical and methodological discussions as well as the use of life history. Depending on the interests of researchers, life history can be observed through different perspectives, as a theoretical and methodological framework, but also as a research method. It allows different ways of in-depth documentation of individual stories within the social context over a certain period and is suitable for exploring a wide spectrum of phenomena, which points to its methodological power. Like other qualitative research methods, the life history approach faces issues related to its reflexive considerations regarding research design, and other specific methodological and ethical issues. On the other hand, its methodological and research benefits in researching various social phenomena indicate the necessity to reconsider the role of the life history approach in contemporary sociological methodology.

Keywords: life history approach, sociology, qualitative methodology, research approaches and method 